\title{
High-density aggregation in queen conch Strombus gigas: formation, patterns, and ecological significance
}

\author{
Allan W. Stoner, James Lally \\ Caribbean Marine Research Center, 805 E 46th Place, Vero Beach, Florida 32963, USA
}

\begin{abstract}
Queen conch Strombus gigas L., an important fisheries species, is often found in large aggregations of very high density $\left(20\right.$ to $\left.300 \mathrm{conch} \mathrm{m}^{-2}\right)$, which move over the bottom in seagrass meadows of the Bahamas. Over the 6 yr period from 1987 to 1992, 25 high-density aggregations were observed in the southern Exuma Cays, Bahamas, 12 of them in a single, well-studied nursery ground. Except for 1 aggregation, all were oriented across tidal currents, but movements in both ebb and flood directions were observed. Aggregations occurred in all Inonths, but predominantly between October and April. This 'mass migration' was hypothesized to serve the purpose of carrying conch from juvenile to adult habitats. Given the lack of progression toward deep-water adult habitats, and the fact that aggregations consisted of different age groups from the $1+$ year class to early adults, it is unlikely that this phenomenon represents ontogenetic movement. Aggregations sometimes formed in the center of homogeneous seagrass beds and are probably not feeding fronts. Most commonly, high-density aggregations formed when juvenile populations were large and when density was increased experimentally, suggesting that formation is density-dependent. A tethering experiment showed that conch in an aggregation experience lower predatory mortality than those in the surrounding nursery area. The most important ecological significance of high-density aggregation appears to be probability refuge from predation, or dilution effect.
\end{abstract}

KEY WORDS: Aggregation · Queen conch · Strombus gigas · Migration · Density-dependent · Gastropod

\section{INTRODUCTION}

Aggregation in marine invertebrates is found in several different forms. Many benthic infauna exhibit negative binomial or other non-random, non-uniform distribution (Heip 1975, Fleeger et al. 1990), and considerable attention has been given to sampling problems associated with contagious distribution (Elliot 1979). Certain barnacles (Crisp \& Meadows 1962, Hoffman 1989), polychaetes (Knight-Jones 1951, Marsden 1991, Pawlik et al. 1991), and echinoderms (Highsmith 1982, Suer \& Phillips 1983) aggregate upon settlement, while other invertebrates form aggregations as benthic juveniles or adults. High-density feeding fronts are frequently observed in urchins (Bernstein et al. 1981, Vadas et al. 1986) and sea stars (Ormond et al. 1973, Scheibling 1980, 1985, Dare 1982). Reproductive aggregations are also common (Heip 1975). Some benthic invertebrates, such as Caribbean spiny lobster Panulirus argus, aggregate in the context of mass migration (Herrnkind 1985), and behaviorally sophisticated forms of aggregation, similar to fish schools, occur in some zooplankton species (Folt 1987, O'Brien 1989) and water striders (Foster \& Treherne 1981).

Aggregation in gastropods is well known, particularly in the families Cerithiidae (Moulton 1962, Skilleter 1991) and Strombidae (Catterall \& Poiner 1983, Stoner \& Ray 1993, Ray \& Stoner 1994), but mechanisms and advantages are little studied. High density, en masse movements in the large and commercially important Caribbean queen conch Strombus gigas L. have been observed recently (Stoner et al. 1988, Stoner 1989a, Lipcius et al. 1991). They hypothesized that mass movement represents ontogenetic migration 
from centers of larval recruitment to deeper juvenile and adult habitats. Other potential functions include reduction of predation-induced mortality and efficient food utilization.

In the present study, observations on 25 queen conch aggregations are compared. Field experiments were conducted to examine the formation and adaptive significance of the aggregation phenomenon.

\section{MATERIALS AND METHODS}

Subject species. Strombus gigas is a large herbivorous gastropod indigenous to subtropical and tropical waters of the western Atlantic from Bermuda and southern Florida to Brazil (Abbott 1974). Pelagic larvae of $S$. gigas live in the water column for 18 to $28 \mathrm{~d}$ before they settle and metamorphose on the sediment (Brownell 1977, Davis et al. 1987). Little is known about early stages of benthic life in queen conch (Sandt \& Stoner 1993); however, 1 yr old juveniles (80 to $100 \mathrm{~mm}$ shell length) are believed to emerge from the sediment and feed epibenthically in seagrass meadows that provide abundant algal and detrital foods (Robertson 1961, Randall 1964, Stoner \& Waite 1991). Sexual maturity is reached at approximately $3.5 \mathrm{yr}$ of age (180 to $270 \mathrm{~mm}$ shell length), which is preceded by the development of a flared shell lip (Egan 1985, Appeldoorn 1988).

Aggregation in queen conch occurs on 2 different scales. First, juveniles on the Great Bahama Bank (especially 1 and 2 yr old) are most abundant in certain shallow-water seagrass meadows. These nursery grounds are characterized by clear oceanic water and high tidal current velocity (Stoner \& Waite 1990, Stoner et al. 1993, A. W. Stoner, P. A. Pitts \& R. A. Armstrong unpubl.). Aggregations within nurseries have densities of 0.2 to 2.0 conch $\mathrm{m}^{-2}$ and provide density-dependent refuge for young conch (Stoner \& Ray 1993, Ray \& Stoner 1994). Second, high-density aggregations (20 to 320 conch $\mathrm{m}^{-2}$ ) are frequently observed within larger juvenile aggregations in the nursery grounds. They form relatively narrow bands that move in a front across the bottom consuming detritus and epiphytes (Stoner 1989a). The first high-density aggregation reported was 140 to $210 \mathrm{~m}$ long, $2.4 \mathrm{~m}$ wide, contained over 100000 juvenile conch, and persisted for several months (Stoner et al. 1988). The phenomenon has been called 'mass migration' (Stoner et al. 1988, Stoner 1989a, Lipcius et al. 1991).

Study site. All of the high-density aggregations investigated in this study were found on Great Bahama Bank adjacent to the Exuma Cays, central Bahama Islands, between Children's Bay Cay and Musha Cay (Fig. 1). The Exuma Cays are a $250 \mathrm{~km}$ long chain of low, carbonate islands, with a narrow shelf $1<2 \mathrm{~km}$ wide) that drops off to deep oceanic waters of Exuma Sound east of the Cays (windward in prevailing conditions). Inlets of varied width separate the small islands. Great Bahama Bank to the west is a 3 to $5 \mathrm{~m}$ deep sand and seagrass Thalassia testudinum covered carbonate platform. The bank extends 25 to $65 \mathrm{~km}$ west from the

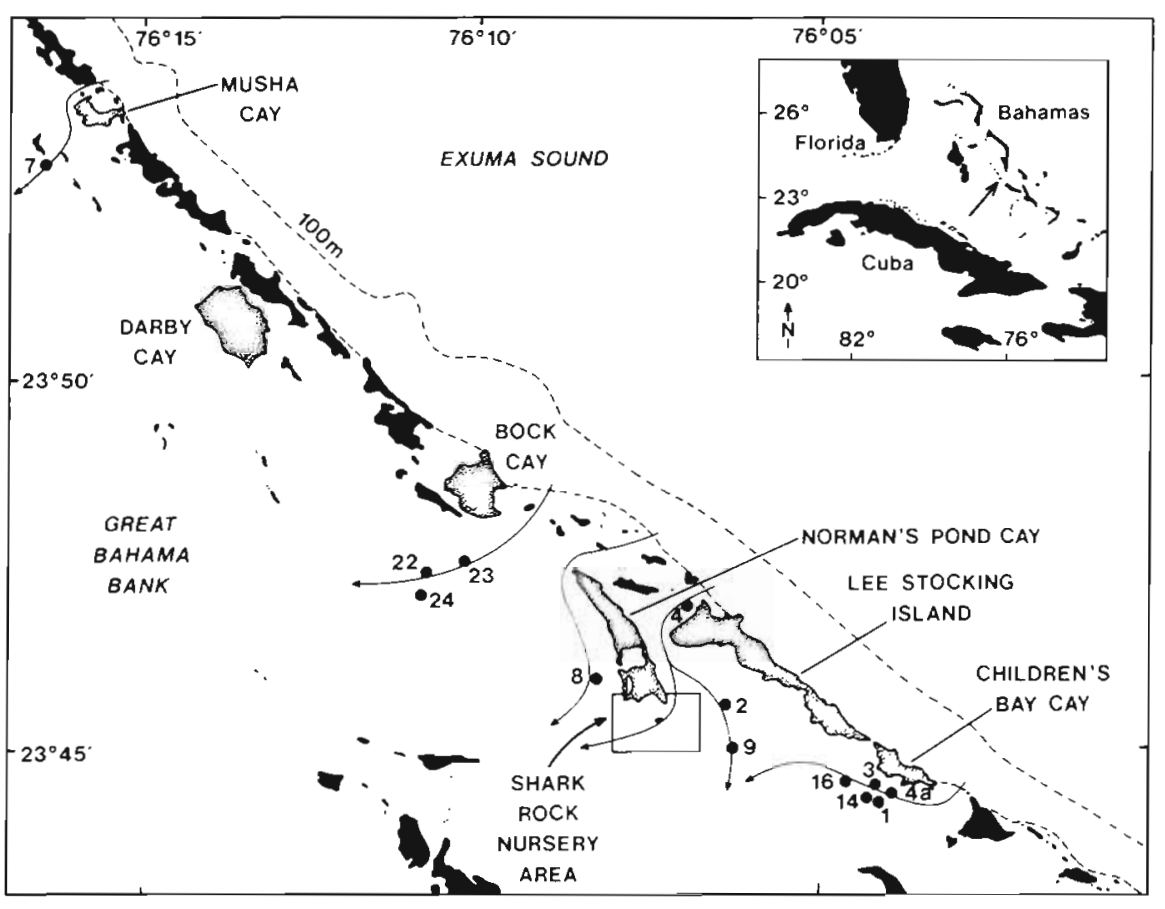

Fig. 1 Strombus gigas. Study site central Bahamas, showing locations of high-density queen conch aggregations discovered between 1987 and 1992. Twelve aggregations found within the Shark Rock nursery site are shown in Fig. 2. Arrows indicate general flow of flood tide waters onto the Great Bahama

Bank near the aggregations 
island chain to the Tongue of the Ocean, another deep basin.

While wind drift is the most important physical component of net transport of water and suspended matter onto Great Bahama Bank from Exuma Sound, semi-diurnal tides, with a range of $1 \mathrm{~m}$, generate strong currents $\left(>100 \mathrm{~cm} \mathrm{~s}^{-1}\right)$ in the vicinity of conch nurseries (Stoner et al. 1993). Because of shallow depth over most of the bank, bottom topography and sand bars govern the physical transport of water.

Twelve of the 25 high-density aggregations investigated were found near Lee Stocking Island at the Shark Rock conch nursery ground (see Stoner \& Waite 1990, Stoner \& Sandt 1991). This is a moderate-density (300 to 500 shoots $\mathrm{m}^{-2}$ ) seagrass Thallasia testudinum site in a 2 to 3 m deep (mean low water, MLW) channel between shallow sand bars (Fig. 2). Juvenile conch have been abundant at this site since at least 1988 (Stoner et al. unpubl.); in 1990, estimates of total population size were between 105000

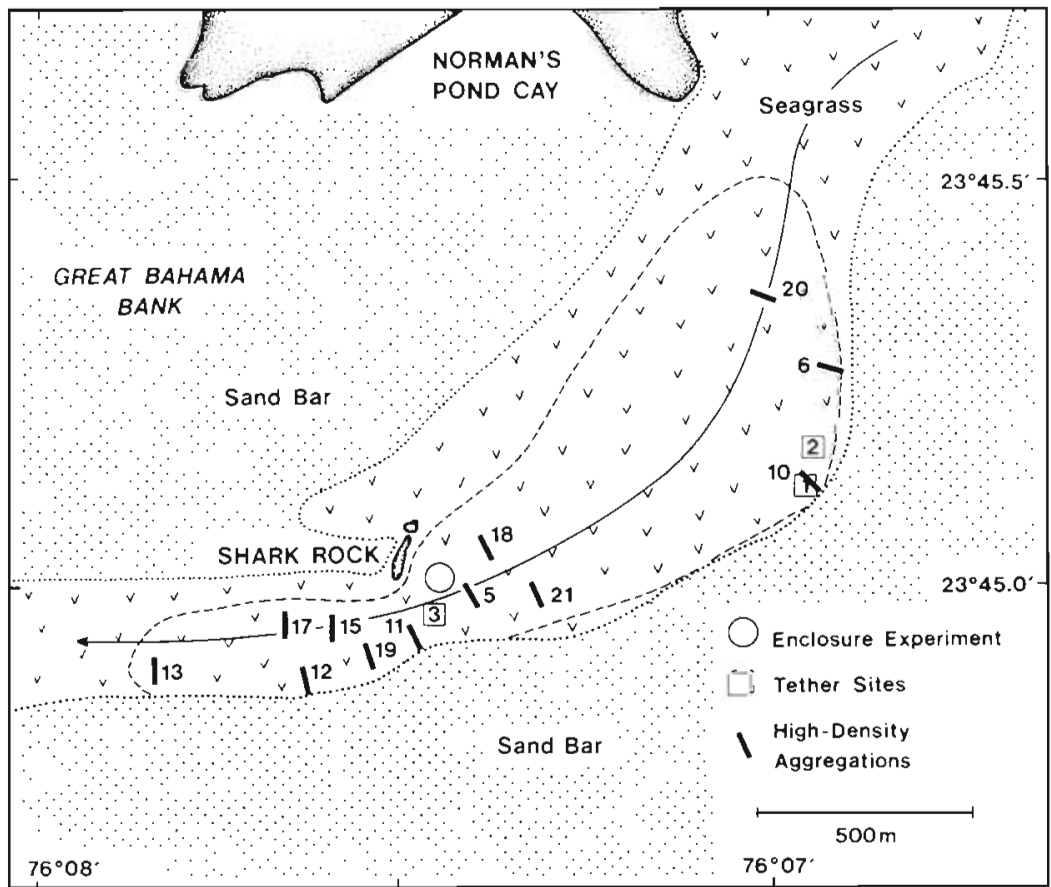

Fig. 2. Strombus gigas. Locations of high-density queen conch aggregations found in the Shark Rock nursery ground between 1987 and 1992. Positions of enclosure $(O)$ and tether $(\square)$ experiments are also shown. Arrow indicates the general flow of flood tide waters onto Great Bahama Bank from Exuma Sound.

Aggregation 18 was induced by releasing 1200 juvenile conch (see text) and 162000 conch (Stoner \& Ray

1993). Manipulative experiments were conducted in the Shark Rock nursery (Fig. 2).

Aggregation measurements. High-density aggregations of queen conch were located in the course of other field studies on the species in the Exuma Cays, over the nearly 6 yr period from April 1987 to November 1992. Conch nurseries near Children's Bay Cay and Shark Rock were sites of intense experimentation between 1988 and 1992. Therefore, we believe that all mass movements of conch in those areas were observed. Aggregations in other areas were found by chance and probably represent only a fraction of the activity.

The edges of high-density aggregations were usually distinct, but considered to be the line at which density was $>2.0$ conch $\mathrm{m}^{-2}$. Length was measured once and width was measured at 3 to 16 locations along an aggregation depending upon its length. Density of conch in an aggregation was estimated by counting conch in haphazardly placed 1.0 or $2.0 \mathrm{~m}^{2}$ plots; the number of plots was in proportion to the size of the aggregation. At least 100 individuals from each aggregation were measured for total shell length (spire to siphonal groove) with large calipers.

Biomass estimates for the aggregations were calculated using the dimensions of aggregations, mean den- sity, size distribution data, and the shell length/tissue weight relationship (Stoner \& Waite 1990),

$\log _{10}($ wet weight $)=3.403 \times \log _{10}($ shell length $)-5.569$ where wet weight is the soft tissue weight in grams and shell length is in $\mathrm{mm}$.

An underwater compass was used to measure the orientation of the axis of each aggregation and heading of the tidal current. Orientations of 40 to 90 individual conch were determined by placing a compass directly over the conch and recording the heading of the anterior end of the shell

In most cases high-density aggregations moved as fronts across the bottom. Progression was measured for numerous persistent aggregations by placing either stakes or buoys along the forward edge of the front and measuring distance traveled over time. Direction of movement was recorded and progression was reported in $\mathrm{m} \mathrm{d}^{-1}$.

Field experiments. Formation of aggregations: Two experiments were conducted to examine whether formation of high-density aggregations is mediated by density. In the first experiment, 1200 dispersed juvenile conch ( 85 to $120 \mathrm{~mm}$ shell length) were collected from the nursery near Shark Rock and released haphazardly in an area of approximately $100 \mathrm{~m}^{2}, 400 \mathrm{~m}$ 
east of the conch source (Fig. 2). The release site was contiguous with and similar to the site where conch were collected (a cover of moderate-density Thalassia testudinum, Thalassia detritus, and the green alga Batophora oerstedi), except that foods such as $B$. oerstedi and detritus were more abundant in the release area. Long-term data show that the $3 \mathrm{~m}$ deep release site was well within the boundaries of historic nursery grounds (Stoner \& Ray 1993, Stoner et al. unpubl.). The release was made on 23 November 1990 and by 3 December 1990, the conch formed a typical highdensity aggregation. Thereafter, the site was visited for observation of the aggregation every 5 to $7 \mathrm{~d}$ for $4 \mathrm{wk}$. A routine set of measurements (described above) was made for the aggregation on 12 December 1990.

A second experiment was conducted to examine how oriented movement of juvenile conch is related to conch density. Three circular pens without tops were built within the Shark Rock nursery area (Fig. 2). These pens $\left(50 \mathrm{~m}^{2}, 30 \mathrm{~cm}\right.$ high) were constructed with $2.5 \times 5.0 \mathrm{~cm}$ vinyl-covered wire mesh fastened to reinforcement bars driven into the sediment. The pens were marked along the perimeter into 8 equal lengths; one of the resulting sectors was oriented in the direction of the flood tide and one with the ebb tide. Six other sectors fell uniformly between these two. To record positions of conch within the pens, lines connecting the markers on the pen to a center stake resulted in 8 identical $45^{\circ}$ wedges that were surveyed.

Juvenile conch ( 85 to $120 \mathrm{~mm}$ shell length) were collected from the adjacent nursery site and dispersed evenly in the 3 pens at densities equivalent to 1,2 , and 5 conch $\mathrm{m}^{-2}$. Two days following introduction, the number of conch in each of the 8 pen sectors and the number in each sector along the walls of the pen were counted. Individuals in contact with other conch touching the walls were considered to be along the walls. The $2 \mathrm{~d}$ experimental duration was chosen after preliminary measurements showed no change in distribution after this time. All introduced conch were accounted for and were alive at the end of the experiment. Density treatments were systematically interspersed among the pens over time, and 3 replicate runs were made with each density level. New animals were used in each run. All experiments were completed between November and nid-December 1990.

Survivorship in aggregations: A tethering experiment was conducted to determine whether survivorship of juvenile queen conch is enhanced for animals living in a high-density aggregation. Juvenile conch (95 to $110 \mathrm{~mm}$ shell length) were tethered within Aggregation 10 (Stn 1), $20 \mathrm{~m}$ ahead of the aggregation in an area with virtually no conch (Stn 2), and in the Shark Rock nursery area where there was a juvenile conch density of 1.0 ind. $\mathrm{m}^{-2}$ (Stn 3) (Fig. 2). Water depth at MLW was $3.2 \mathrm{~m}$ at Stns $1 \& 2$, and $3.0 \mathrm{~m}$ at Stn 3 . The bottom at all sites was firm sand covered with moderate-density seagrass Thallasia testudinum, seagrass detritus, and small clumps of the green alga Batophora oerstedi.

A total of 25 conch were tethered individually at each station. A clear nylon cable tie was secured around the spire of the shell. One end of monofilament line ( $8 \mathrm{~kg}$ test) was attached to the cable tie and the other end to a $40 \mathrm{~cm}$ long stainless steel welding rod that was pushed into the sediment. Tagged tether rods were placed at approximately $2 \mathrm{~m}$ intervals in straight lines across the tidal current. Line length was $1.5 \mathrm{~m}$ at Stns $2 \& 3$. At Stn 1 line length was $3.0 \mathrm{~m}$ to accommodate the daily progression of the mass movement. Every 2 to $3 \mathrm{~d}$ the tether rods were set $3 \mathrm{~m}$ ahead of the progression so that tethered conch were always in the aggregation as it progressed over the bottom. To simulate the disturbance effect of moving tethers at Stn 1 . tethers at Stns $2 \& 3$ were also moved approximately $3 \mathrm{~m}$ every 2 to $3 \mathrm{~d}$. This also allowed the tethers placed at Stn 2, ahead of the aggregation, to remain $20 \mathrm{~m}$ away as Aggregation 10 advanced. Tethers were first set on 5 December 1989, moved and checked for mortality every 2 to $3 \mathrm{~d}$ until 30 December.

It is recognized that mortality on tethers does not constitute absolute measures of natural mortality at particular sites, but does provide an estimate of relative mortality. Previous studies (Marshall 1992, Stoner $\&$ Davis 1994) have shown that the restriction of tethers does not result in significantly diminished growth rates, particularly in a short-term experiment such as this. The experiment was conducted only once.

\section{RESULTS}

\section{Aggregation measurements}

General distribution and seasonality

All of the high-density aggregations were found on Great Exuma Bank in less than $4 \mathrm{~m}$ of water. Of $25 \mathrm{mi}-$ grations, 16 were located within well-studied nursery grounds at Shark Rock and near Children's Bay Cay (Fig. 1). Others were discovered in areas without longterm data on conch distribution, but most are known to be sites where juvenile conch are common. Aggregation 4, observed in late August 1988, was the only aggregation located close to the Exuma Sound and was in an area not particularly known for juvenile conch (Fig. 1).

Aggregations were observed in every month of the year (Fig. 3). March, however, had highest numbers of aggregations (10), and only 3 were well formed in the warmer months of June through September. At Shark 
Rock, where all aggregations were probably encountered over the $4 \mathrm{yr}$ period from 1989 to 1992 , all occurred between October and April. Cool water temperature, therefore, may influence formation and maintenance of aggregations. However, the largest aggregation (no. 1) occurred in mid-summer 1987 .

Given that most aggregations were probably found days to weeks or even months after formation, it is only possible to discuss duration of aggregations at the well-studied sites. Aggregation 1 is known to have been well defined for at least $5 \mathrm{mo}$, and this was also the largest observed. Frequent visits to the Shark Rock nursery area revealed 12 aggregations between 1989 and 1992 (Fig. 2). Three of these (nos. 10, 11, 12), occurring in late 1989 to early 1990, were active for 3 mo or more. Several smaller aggregations, present between late 1990 and early 1991 (nos. $15,17,18,19,20,21$ ), were well defined for periods of less than 2 mo.

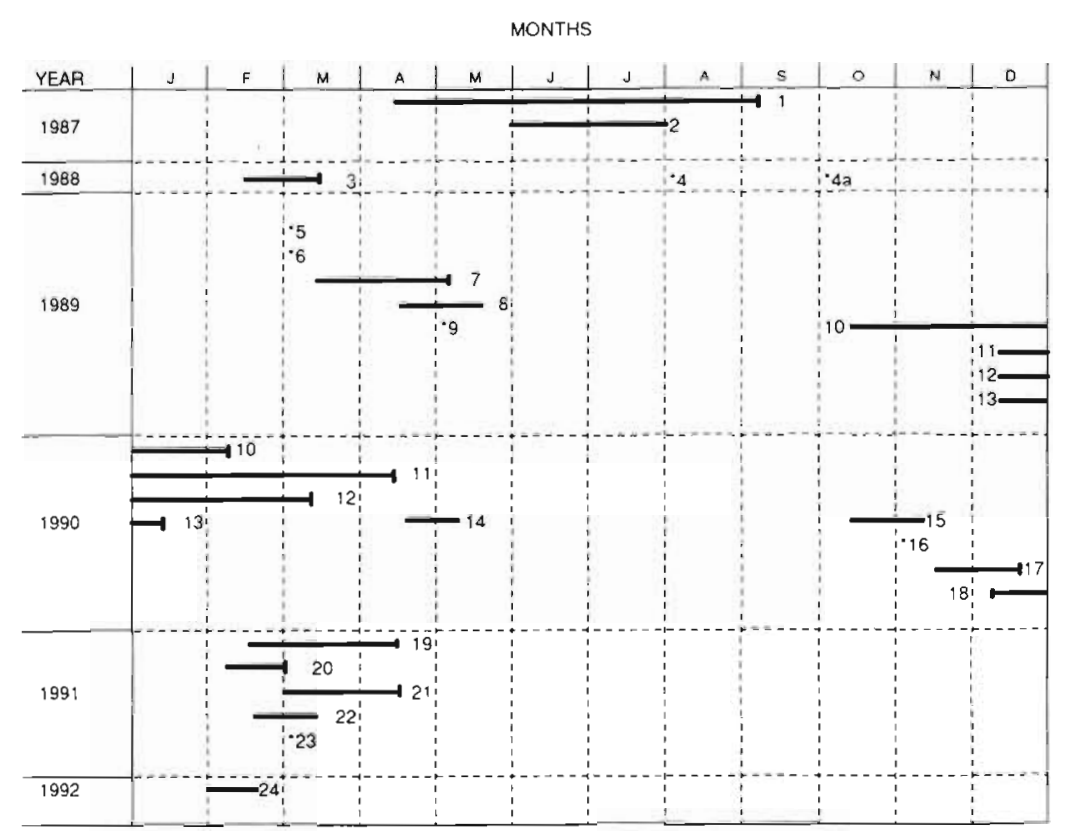

Fig. 3. Strombus gigas. Calendar of 25 high-density queen conch aggregations found in the Exuma Cays, Bahamas, 1987-1992. A bar at the right end of a line indicates dispersion of the aggregation. Lack of a bar shows that the end of the aggregation was not observed. Aggregations for which only 1 observation was made. The beginning date was known for Aggregation 18 because it was induced experimentally

\section{Dimensions and age structure}

Densities and dimensions were measured for 16 of the 25 high-density aggregations found. The average $( \pm \mathrm{SD}$ ) length of the 16 aggregations was $78 \mathrm{~m}( \pm 40)$, with large variation in aggregation size (28 to $160 \mathrm{~m}$ ) (Table 1). Average width was $2.8 \mathrm{~m}$ ( \pm 1.8 ), with a range from 1.0 to $7.5 \mathrm{~m}$ (Table 1). Aggregation 9, observed in May 1989, at a site not known as a nursery ground, was unusual in its great width $(7.5 \mathrm{~m})$ and large mean shell length $(171 \mathrm{~mm})$ (Table 1$)$. It was composed mostly of adult (43\%) and $3+$ year class juveniles $(57 \%)$. This was the only aggregation with a high proportion of adult conch, although several other aggregations (especially nos. 10, 21 \& 24) were dominated numerically by large juveniles. Density of conch in Aggregation 9 was just 2.5 conch $\mathrm{m}^{-2}$; however, a typical band-like form was well defined.

Average density in aggregations was 69 conch $\mathrm{m}^{-2}$, with a range from 2.5 to 295 (Table 1), and there was a weak negative correlation between mean conch size in an aggregation and $\log _{10}$ density $\left(R^{2}=0.529, F_{1,14}=\right.$ $15.72, p=0.001)\left(\log _{10}\right.$-transformation of the data removed heterogeneity of variance in density data). In

- One measurement of Aggregation 1 during its 5 mo duration yielded a total length of $210 \mathrm{~m}$ (Stoner et al. 1988)
mid-April 1987. Aggregation 1 had a density of 295 conch $\mathrm{m}^{-2}$, a total surface area of $384 \mathrm{~m}^{2}$, and contained approximately 113280 individuals. Most of the other aggregations contained $<10000$ conch (Table 1 ).

Mean biomass in aggregations was $2.4 \mathrm{~kg} \mathrm{~m}^{-2}$ (SD = 1.7 ), with a range from 0.25 to $5.27 \mathrm{~kg} \mathrm{~m}^{-2}$ (Table 1). The largest aggregation (no. 1) had the highest total biomass, estimated at over $1 \mathrm{t}$ of soft tissue. Despite the presence of adult conch, Aggregation 9 had low animal density and low total biomass $(200 \mathrm{~kg})$.

\section{Orientation}

There was a strong relationship between orientation of the axis of aggregations and direction of the tidal current (Table 2). Of the 16 aggregations measured, 15 were oriented between 55 and $90^{\circ}$ of tidal current direction, and $10(63 \%)$ were within $10^{\circ}$ of perpendicular to the current $\left(80\right.$ to $\left.90^{\circ}\right)$. Only Aggregation 8 diverged from this pattern; its axis was nearly parallel to the tidal current $\left(20^{\circ}\right.$ difference).

To examine orientations of individuals within 15 different aggregations, orientation data were divided into 4 quarters of the compass related to tidal current direction (i.e. $90^{\circ}$ arc centered on ebb tide direction, $90^{\circ}$ centered on flood tide direction, etc.). Chi-square tests 
Table 1 Strombus gigas. Dimensions and surface area of 16 high-density queen conch aggregations measured in the Exuma Cays, Bahamas, between 1987 and 1992. Conch density, size, and wet tissue biomass are also reported for each aggregation. Total conch numbers and biomass were estimated on the basis of aggregation dimensions, density, and a known length-weight relationship (see text). For width, density, and conch length, values are mean $\pm \mathrm{SD}(\mathrm{n})$

\begin{tabular}{|c|c|c|c|c|c|c|c|c|}
\hline $\begin{array}{c}\text { Aggreg. } \\
\text { no. }\end{array}$ & $\begin{array}{l}\text { Length } \\
\text { (m) }\end{array}$ & $\begin{array}{l}\text { Width } \\
\text { (m) }\end{array}$ & $\begin{array}{l}\text { Area } \\
\left(\mathrm{m}^{2}\right)\end{array}$ & $\begin{array}{c}\text { Density } \\
\left(\text { conch } \mathrm{m}^{-2}\right)\end{array}$ & $\begin{array}{c}\text { Conch length } \\
\text { (mm) }\end{array}$ & $\begin{array}{c}\text { Biomass } \\
\left(g \mathrm{~m}^{-2}\right)\end{array}$ & $\begin{array}{c}\text { Total no. } \\
\text { conch }\end{array}$ & $\begin{array}{l}\text { Total bio- } \\
\text { mass }(\mathrm{kg})\end{array}$ \\
\hline 1 & 160 & $2.4 \pm 1.1(16)$ & 384 & $295 \pm 78$ & $101 \pm 13(256)$ & 5266 & 113280 & 2022 \\
\hline 3 & 44 & $1.0 \pm 0.2$ & 44 & $92 \pm 10$ & $135 \pm 11(128)$ & 4409 & 4048 & 194 \\
\hline $4 a$ & 83 & $1.0 \pm 0.2$ & 83 & $45 \pm 7$ & $114 \pm 9 \quad(134)$ & 1213 & 3735 & 101 \\
\hline 7 & 60 & $1.8 \pm 0.7$ & 108 & $55 \pm 8$ & $132 \pm 19$ & 2441 & 5940 & 641 \\
\hline 8 & 168 & $6.4 \pm 0.9$ & 1075 & $6.9 \pm 0.7(6)$ & $125 \pm 12 \quad(80)$ & 254 & 7417 & 273 \\
\hline 9 & 100 & $7.5 \pm 1.8$ & 750 & $2.5 \pm 0.8(5)$ & $171 \pm 18 \quad(50)$ & 267 & 1875 & 200 \\
\hline 10 & 60 & $2.2 \pm 0.6$ & 132 & $20 \pm 0.5(3)$ & $149 \pm 21$ & 1341 & 2640 & 177 \\
\hline 11 & 65 & $1.9 \pm 0.3$ & 124 & $99 \pm 17 \quad(5)$ & $107 \pm 24$ & 2151 & 12276 & 267 \\
\hline 14 & 62 & $2.2 \pm 1.1$ & 136 & $13 \pm 25$ (3) & $112 \pm 16(100)$ & 3053 & 17952 & 415 \\
\hline 15 & 28 & $2.5 \pm 0.2$ & 70 & $95 \pm 6$ & $140 \pm 10(100)$ & 5152 & 6650 & 406 \\
\hline 17 & 48 & $2.5 \pm 0.8$ & 120 & $75 \pm 23$ & $123 \pm 14 \quad(60)$ & 2618 & 9000 & 159 \\
\hline 18 & 39 & $2.2 \pm 0.4$ & 86 & $36 \pm 8 \quad(4)$ & $125 \pm 17$ & 1328 & 3096 & 114 \\
\hline 19 & 105 & $2.2 \pm 0.2$ & 231 & $29 \pm 8$ & $142 \pm 12$ & 1651 & 6699 & 381 \\
\hline 21 & 66 & $2.6 \pm 1.2$ & 172 & $17 \pm 4$ & $148 \pm 10 \quad(50)$ & 1114 & 2924 & 192 \\
\hline 23 & 97 & $1.3 \pm 0.5$ & 126 & $87 \pm 17$ & $136 \pm 14$ & 4275 & 10962 & 539 \\
\hline 24 & 59 & $4.6 \pm 2.5$ & 271 & $18 \pm 4$ & $158 \pm 17(100)$ & 1498 & 4878 & 406 \\
\hline
\end{tabular}

showed that all but 2 of the aggregations had individuals which were oriented in a pattern which departed significantly from random $(\mathrm{p}<0.05)$ (Table 3 ). Individuals in Aggregations 7 \& 15 demonstrated random orientation, but in most aggregations a high proportion of

Table 2. Strombus gigas. Relationship between tidal current direction and orientation of 16 high-density queen conch aggregations observed in the Exuma Cays, Bahamas, between 1987 and 1992. Orientation: compass bearing of the long axis of an aggregation using bearing $<180^{\circ}$ Difference between current direction and aggregation orientation is the minimum angle $\left(90^{\circ}\right)$. All directions given in degrees magnetic

\begin{tabular}{|cccc|}
$\begin{array}{c}\text { Aggregation } \\
\text { no. }\end{array}$ & $\begin{array}{c}\text { Tidal current } \\
\text { direction } \\
\text { (ebb/flood) }\end{array}$ & $\begin{array}{c}\text { Orientation } \\
\text { of the } \\
\text { aggregation }\end{array}$ & $\begin{array}{c}\text { Difference } \\
\text { between } \\
\text { current and } \\
\text { aggregation } \\
\text { orientation }\end{array}$ \\
\hline 1 & $110^{\circ} / 290^{\circ}$ & $40^{\circ}$ & $70^{\circ}$ \\
3 & $120^{\circ} / 300^{\circ}$ & $30^{\circ}$ & $90^{\circ}$ \\
$4 \mathrm{a}$ & $30^{\circ} / 210^{\circ}$ & $120^{\circ}$ & $90^{\circ}$ \\
7 & $80^{\circ} / 260^{\circ}$ & $170^{\circ}$ & $90^{\circ}$ \\
8 & $120^{\circ} / 300^{\circ}$ & $100^{\circ}$ & $20^{\circ}$ \\
9 & $50^{\circ} / 230^{\circ}$ & $150^{\circ}$ & $80^{\circ}$ \\
10 & $15^{\circ} / 195^{\circ}$ & $120^{\circ}$ & $75^{\circ}$ \\
11 & $50^{\circ} / 230^{\circ}$ & $150^{\circ}$ & $80^{\circ}$ \\
14 & $120^{\circ} / 300^{\circ}$ & $25^{\circ}$ & $85^{\circ}$ \\
15 & $90^{\circ} / 270^{\circ}$ & $190^{\circ}$ & $80^{\circ}$ \\
17 & $60^{\circ} / 240^{\circ}$ & $150^{\circ}$ & $90^{\circ}$ \\
18 & $50^{\circ} / 230^{\circ}$ & $150^{\circ}$ & $80^{\circ}$ \\
19 & $0^{\circ} / 180^{\circ}$ & $125^{\circ}$ & $55^{\circ}$ \\
21 & $10^{\circ} / 190^{\circ}$ & $125^{\circ}$ & $65^{\circ}$ \\
23 & $90^{\circ} / 270^{\circ}$ & $30^{\circ}$ & $60^{\circ}$ \\
24 & $110^{\circ} / 290^{\circ}$ & $20^{\circ}$ & $90^{\circ}$ \\
\hline
\end{tabular}

individuals were oriented in a direction across the axis of the aggregation. In Aggregation 8, a high proportion of conch were oriented across the tidal current, and this was the only aggregation that moved across rather than with either the ebb or flood tide (see next section).

Table 3. Strombus gigas. Orientations of individual conch within 15 high-density aggregations relative to direction of ebb and flood tidal currents in the Exuma Cays, Bahamas, 1987-1992. N: no. of individual observations made. Other values are percentages of the total number of conch oriented in $90^{\circ}$ sectors centered on direction of ebb tide, flood tide, and across the current to the right $(\mathrm{R})$ or left $(\mathrm{L})$ of flood current direction. Results of chi-square are shown to indicate whether orientations depart significantly $(" p<0.05)$ or not significantly $(\mathrm{p}>0.05, \mathrm{~ns})$ from uniform distribution in 4 sectors

\begin{tabular}{|c|c|c|c|c|c|c|}
\hline \multirow{2}{*}{$\begin{array}{c}\text { Aggreg. } \\
\text { no. }\end{array}$} & \multirow[t]{2}{*}{$\mathrm{N}$} & \multicolumn{5}{|c|}{ Individual orientations } \\
\hline & & Ebb & Flood & $\mathrm{R}$ & $\mathrm{L}$ & Chi-square \\
\hline 1 & 54 & 72 & 6 & 7 & 15 & $\cdot$ \\
\hline 3 & 50 & 85 & 0 & 0 & 15 & $\cdot$ \\
\hline 7 & 64 & 41 & 20 & 16 & 23 & ns \\
\hline 8 & 50 & 16 & 24 & 42 & 18 & $\cdot$ \\
\hline 9 & 40 & 65 & 2 & 8 & 25 & • \\
\hline 10 & 83 & 8 & 53 & 28 & 11 & • \\
\hline 11 & 60 & 73 & 6 & 6 & 15 & " \\
\hline 14 & 72 & 56 & 10 & 29 & 5 & ' \\
\hline 15 & 50 & 18 & 22 & 42 & 18 & ns \\
\hline 17 & 48 & 61 & 2 & 29 & 8 & • \\
\hline 18 & 48 & 2 & 69 & 10 & 19 & $\cdot$ \\
\hline 19 & 46 & 63 & 4 & 7 & 26 & •" \\
\hline 21 & 50 & 64 & 24 & 6 & 6 & " \\
\hline 23 & 65 & 70 & 0 & 18 & 12 & " \\
\hline 24 & 50 & 50 & 8 & 30 & 12 & ' \\
\hline
\end{tabular}


Progression and dispersion

Mass movement was measured for 9 different aggregations (Table 4). Average progression was $3.0 \mathrm{~m} \mathrm{~d}^{-1}$ ( $\mathrm{SD}=0.8)$; however, detailed analysis of Aggregations 1 \& 3 (Stoner et al. 1988, Stoner 1989a) and other casual observations have shown that progression is highly variable over time. Movement increased when aggregations encountered areas with low food supply, decreased when heavy algal mats were encountered, and might stop temporarily during heavy wave action and low temperature periods which occur during winter months (Stoner 1989a, pers. obs.).

Of the 9 aggregations, 4 moved with the ebb tide, 4 moved with the flood tide, and Aggregation 8 moved across the tide. Given that all of these aggregations progressed in the direction in which individual conch were oriented, it is assumed that individual orientation, where significant, provides an indication of movement. With this assumption, data on orientation (Table 3) and field notes for 24 aggregations, the following may be concluded: $15(62.5 \%)$ of the aggregations moved in the direction of ebb tide current, 8 $(33.3 \%)$ progressed with the flood tide, and 1 moved across the tidal current.

Movements in ebb tide direction occurred in all months except January and September, while aggregations moving in flood tide direction were not recorded between June and October. Therefore, despite the fact that high-density aggregation appears to occur year round, there may be some seasonality in direction of movement. As discussed earlier, however, only 3 summer aggregations were observed.

Aggregations may change direction as observed in Aggregation 11. This aggregation progressed in flood tide direction (toward the west) at approximately $2.9 \mathrm{~m}$ $\mathrm{d}^{-1}$ for the first 3 mo of observation, then reversed direction to advance toward the east approximately 1 mo before dispersing in mid-April 1990. Reversal of direction and dispersion appeared to be related to movement of conch into and around an area that contained high densities of foods such as the green alga Batophora oerstedi.

Dispersion also occurred when the ends of several aggregations (including nos. 1, 12 \& 15) encountered bare sand habitat. In these cases, individual movements appeared to accelerate, in near random direction, probably because of the lack of macroalgal and/or detrital foods. Most aggregations, however, dispersed slowly over periods of weeks to months, with animals dropping off the following edge of the aggregation as it progressed over the seagrass meadow. Dispersion rate was calculated for Aggregation 3, using tagged individuals (Stoner 1989a), but the experiment was not repeated.
Table 4. Strombus gigas. Progression of high-density queen conch aggregations over seagrass meadows in the Exuma Cays, Bahamas, determined by placement of stakes or buoys at the leading edge of front-like aggregates. Direction of movement is shown relative to tidal current

\begin{tabular}{|ccc|}
\hline Aggregation no. & $\begin{array}{c}\text { Progression } \\
\left(\mathrm{m} \mathrm{d}^{-1}\right)\end{array}$ & $\begin{array}{c}\text { Direction of } \\
\text { movement }\end{array}$ \\
\hline 1 & 4.8 & Ebb \\
3 & 2.7 & Ebb \\
8 & 3.2 & Across \\
10 & 2.5 & Flood \\
11 & 2.9 & Flood (later ebb) \\
12 & 2.3 & Flood \\
15 & 2.4 & Ebb \\
17 & 2.5 & Ebb \\
18 & 3.6 & Flood \\
\hline
\end{tabular}

\section{Field experiments}

\section{Formation of aggregations}

Aggregation 18, included in the previously discussed analyses, was induced by the release of 1200 juvenile conch in the Shark Rock nursery area in November 1990. This $39 \mathrm{~m}$ long aggregation formed during a period of only a few days after releasing the conch in a resultant density of approximately 12 conch $\mathrm{m}^{-2}$. Once formed the aggregation had a density of 36 conch $\mathrm{m}^{-2}$, and progressed in flood tide direction at a rate of $3.6 \mathrm{~m}$ $\mathrm{d}^{-1}$. All features were typical of naturally formed aggregations. Given that conch used in the experiment were not taken from an aggregation, it is unlikely that they were predisposed in any unusual way to initiate mass movement. Foods such as Thalassia testudinum detritus and Batophora oerstedi were abundant at the release site and it is also unlikely that food was limiting.

Density-dependence in tendency to move in an oriented manner was also demonstrated in the enclosure experiment. In the 1 conch $\mathrm{m}^{-2}$ treatment, there was a relatively even distribution of conch in the 8 pen sectors, with only $4 \%$ of the individuals touching the walls (Fig. 4). Chi-square tests showed that 2 runs did not depart from the expected even frequency distribution over pen sectors $(p>0.05)$, while the third run had higher than expected numbers of conch in certain sectors $\left(\chi^{2}=14.32, p<0.05\right)$. In this run conch were significantly more abundant in sectors on the west side of the pen, reflecting movement in flood tide direction. Strength of response increased with conch density (Fig. 4). At 2.0 conch $\mathrm{m}^{-2}, 26 \%$ of the animals were found in the west sector and $22 \%$ were against the side of the pen. Chi-square tests indicated that all 3 runs departed from even distribution in the 8 pen sectors 


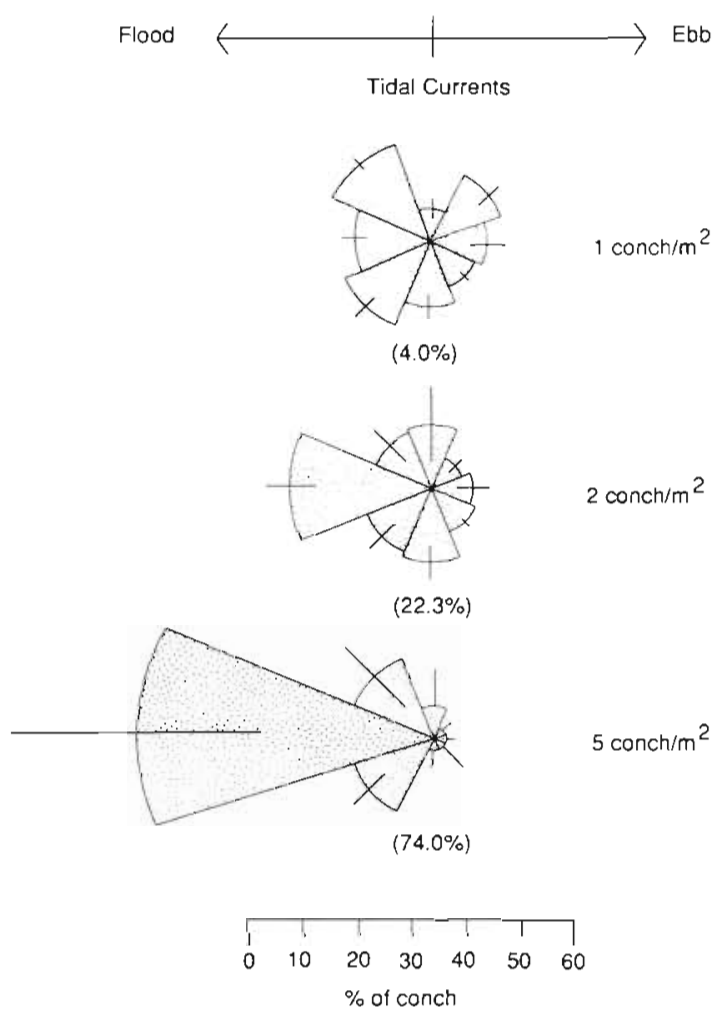

Fig. 4. Strombus gigas. Location of juvenile queen conch within $50 \mathrm{~m}^{2}$ circular enclosures for 3 different density treatments. Percentage of total conch in each of 8 equal sectors (relative to tidal current direction) is indicated by the radius of each wedge. Error bars = SD. Total percentages of conch on enclosure walls are shown in parentheses

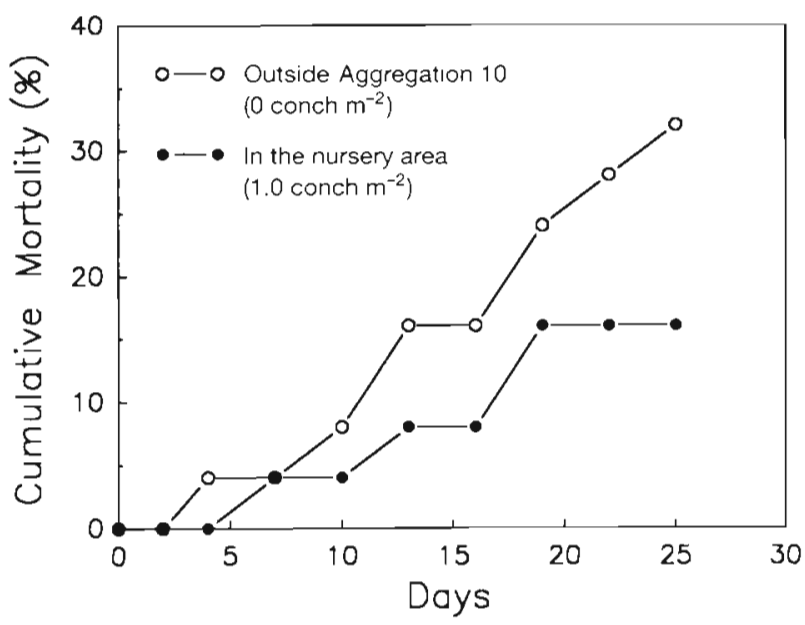

Fig. 5. Strombus gigas. Mortality of tethered juvenile queen conch in the Shark Rock nursery area, with an ambient conch density of 1 conch $\mathrm{m}^{-2}$, and at an area $20 \mathrm{~m}$ from Aggregation 10 where there were no other conch. There was no mortality observed over the $25 \mathrm{~d}$ duration of the experiment for conch tethered within Aggregation 10 $(p<0.05)$. At 4.0 conch $\mathrm{m}^{-2}, 55 \%$ of all conch were in the west sector, with a highly significant difference from uniform distribution in all runs (Chi-square tests, $p<0.001$ ), and $74 \%$ of the conch were on the pen sides.

\section{Survivorship in aggregations}

Although statistical comparison of treatments is not possible given the lack of replication, the tether experiment showed clearly that relative rate of predatorinduced mortality was lower inside high-density Aggregation 10 than in the surrounding areas (Fig. 5). Over the 25 d experimental period no mortality occurred in the aggregation, while $32 \%$ of the conch were killed only $20 \mathrm{~m}$ away in an area without juvenile conch (Stn 2). Within the nursery area (Stn 3) (1.0 conch $\mathrm{m}^{-2}$ ) $16 \%$ of the tethered animals were killed. All of the shells of killed conch were found attached to the tethers; most were chipped slightly on the lip edge and occupied by hermit crabs. Given the lack of crushed shells and relatively minor shell breakage, predation was probably caused by molluscs such as tulip snail Fasciolaria tulipa and octopi.

\section{DISCUSSION}

Despite the fact that queen conch provide an important fishery in the Caribbean region (Brownell \& Stevely 1981), the first report of high-density aggregation was published only recently (Stoner et al. 1988). New data presented here show that such aggregation is a common phenomenon in historically important nursery areas. On one date in 1990. Stoner \& Ray (1993) showed that over $13 \%$ of the conch population at the Shark Rock nursery site was distributed in 4 small high-density aggregations. At the Children's Bay Cay nursery, one aggregation contained over 100000 juvenile conch for nearly $5 \mathrm{mo}$ in 1987 and comprised at least half of the local population. Given the regularity of occurrence and high percentage of conch in high-density aggregations, this phenomenon has an important role in population dynamics, and should be considered in any stock assessment or fisheries management plan.

The present study shows that our earlier classification of high-density queen conch aggregation as mass migration was not correct technically. In all cases where progression was measured, conch were moving en masse and the movement was oriented by tidal current direction; however, orientation and movement were not rhythmic or predictable on a seasonal or other time scale. Also, the earlier hypothesis that 'mass 
migration' represents a form of ontogenetic migration to deeper adult habitat was not borne out by further observation. Movement was in the direction of either flood or ebb tide while only the latter would carry queen conch toward deep channels and the island shelf where older conch are most abundant. Although high-density aggregation was observed primarily in 1 and 2 yr old conch, older juveniles and adults also formed aggregations, and it appears unlikely that aggregation is a function of synchronous emergence of the first year class from the sediment as hypothesized by Stoner et al. (1988).

An alternative to the migration hypothesis is that aggregations are feeding fronts, analogous to those observed in urchins (Bernstein et al. 1981, Vadas et al. 1986). Although conch aggregations can significantly reduce the standing crops of macroalgae, detritus, and seagrass epiphytes with their passage (Stoner 1989a), and progression of aggregations was related to food quantity in this study, one would expect feeding fronts to progress in an oriented fashion relative to the food resource instead of other physical factors. Ninety-six percent of the aggregations observed in this study progressed in the direction of either flood or ebb tidal currents, not food gradients.

Growth rates of juvenile queen conch are sometimes higher outside normal, low-density nursery aggregations than inside, and the difference is highest in the winter when food production is lowest (Stoner \& Ray 1993, Ray \& Stoner 1994). This suggests that densitydependent pressures are greatest in winter and may explain the predominantly winter occurrence of mass movement in conch. However, high-density aggregation in winter is paradoxical in that it would exacerbate inversely density-dependent growth rates.

Several lines of evidence suggest that high-density conch aggregations are induced by increasing animal density in a nursery ground and independent of foods. First, a typical aggregation (no. 18) was induced by increasing the density of conch in the middle of a homogeneous seagrass meadow with high standing crop of a preferred food, Bathophora oerstedi. A similar phenomenon occurred in 1990 when an attempt was made to increase conch density in a local area around predation experiments at Lee Stocking Island (L. S. Marshall pers. comm.). Second, tide-oriented movement increased strongly in our enclosures with increased conch density. The response was very rapid and observed in an area where food was not limiting. Third, annual variation in aggregation formation was related to total population size and conch density in the Shark Rock nursery where exhaustive searches for aggregations were made between 1989 and 1992. Four aggregations, one with over 12000 conch, were observed in late 1989 and early 1990, when density of juveniles in the nursery was $>1.0 \mathrm{~m}^{-2}$ over a large area (Stoner \& Ray 1993, Stoner et al. unpubl.). In late 1990, there were 3 small aggregations observed in the nursery, and none were found in the last half of 1991 or in 1992. This reduction in aggregation was associated with a steady decline in the Shark Rock population over the 4 yr period. By mid-1991, conch densities were $<0.2$ conch $\mathrm{m}^{-2}$ over most of the nursery area (Ray \& Stoner 1994). Decreasing numbers of conch at the Shark Rock site appear to be associated with decreasing larval supply (A. W. Stoner unpubl. data).

It has been debated whether front-like aggregations of urchins are formed in response to habitat features and grazing effects, or as a response to predator presence (Bernstein et al. 1981, Tegner \& Levin 1983, Vadas et al. 1986, Scheibling \& Hamm 1991). It is possible that high-density aggregations of queen conch form during periods of high predator abundance; however, this seems unlikely given that aggregations were most numerous in winter months when, in general, predation rates are lowest (Marshall 1992, Stoner \& Davis 1994).

Regardless of the terms applied and the mechanisms of formation, high-density aggregation in queen conch may have great adaptive significance. A vast literature has accumulated on the importance of group living in animals (reviews by Wilson 1975, Bertram 1978, Pulliam \& Caraco 1984) with much interest in modeling ecological advantages of aggregation (e.g. Brock \& Riffenburgh 1960, Hassell 1978, Kidd 1982, Folt 1987. Turchin 1989). Aggregative behavior is usually associated with increasing efficiency in reproduction, foraging, or predator avoidance (Heip 1975, Bertram 1978). The first 2 adaptations can probably be ruled out for queen conch. None of the 25 aggregations occurred on known spawning grounds, and all but one consisted of sexually immature animals. $43 \%$ of Aggregation 9 were conch with flared shell lips, but all of these were young, thin-shelled adults and it is unlikely that they were ready to spawn (Appeldoorn 1988). Efficiency in foraging is equally unlikely because growth in queen conch is inversely density-dependent, particularly at densities $>2.0$ ind. $\mathrm{m}^{-2}$ (Stoner 1989b, Ray \& Stoner 1994), and stomachs of conch within high-density aggregations contain less food than those outside aggregations (Stoner 1989a). Foraging advantages realized by aggregations of vertebrates, such as reduced search time and group capture of prey (Wilson 1975, Bertram 1978), seem unlikely for a slow-moving, generalized herbivore such as Strombus gigas.

Advantages to the group in avoiding predation are more plausible, particularly in light of our small tethering experiment. Several predation-related advantages of aggregation have been listed (Bertram 1978, Pulliam \& Caraco 1984): (1) avoiding detection, (2) early detec- 
tion of the predator, (3) cooperative defense or confusion of the predator, (4) minimizing vulnerability to predation by being in the middle of a group ('selfish herd' hypothesis), and (5) reducing the probability of being attacked by being a member of a large group ('probability refuge' or 'dilution effect'). Although queen conch possess eyes and olfactory apparatus efficient in detecting some predators, locomotory powers are relatively small compared to those of many conch predators. Defense is provided by the heavily spined shell, fending off with the sharp operculum, and some ability to flee from certain slow-moving predators. Group defense mechanisms based upon cooperative behavior seem unlikely. Because high-density aggregations are highly visible and may emit a strong chemical signal to predators, it is unlikely that aggregation reduces detection. However, being in the center of an aggregation would provide a defense mechanism for individuals against smaller predators such as tulip snail Fasciolaria tulipa and hermit crabs. Queen conch juveniles have long apical spines that interlock when the animals are closely packed. This may make it difficult to turn a shell to expose the more vulnerable aperture, or to extract one shell from the mass. The same mechanism could also defend conch from large elasmobranch predators such as spotted eagle ray Aetobatus narinari.

Dilution effect, being one of thousands of alternative prey, is also a plausible advantage to conch in highdensity aggregations. Even $100 \mathrm{~mm}$ conch are relatively large, difficult prey to handle and the largest predators probably consume only a few conch per day. Safety in numbers may be further enhanced by behavior that draws conch into the center of an aggregation, such as that observed in schools of fishes (Major 1977). squid (Hurley 1977), and euphausiids (O'Brien 1989). Unlike fish schools or herds, however, the herding tendency in conch is temporary and aggregations disperse over time.

Regardless of the precise mechanisms, we conclude that high-density aggregation in queen conch is an active process, not a simple feeding front phenomenon. The tether experiment provides evidence that aggregative behavior provides refuge for individuals. If high-density aggregation is dependent upon local population size or density, and if such aggregations reduce natural mortality of juvenile conch in nursery areas, it follows that slow recovery of depleted stocks in many regions of the Caribbean (Appeldoorn et al. 1987. Berg \& Olsen 1989) is exacerbated not only by low numbers of reproductive conch but also by nonlinear, inversely density-dependent mortality.

Because of their large size and slow movement, queen conch can be manipulated easily. The seagrass meadows where conch are abundant are relatively homogeneous, and aggregation can be examined in 2 dimensions unlike fish schools. Additionally, individual defense mechanisms are simple and aggregation is not confounded by reproductive behavior. For all of these reasons the queen conch system is particularly promising for future empirical and experimental research related to aggregation in marine organisms.

Acknowledgements. This research was supported by a grant from the National Undersea Research program of NOAA (U.S. Department of Commerce). A. Bardales, R. Gomez, R. Lipcius, L. Marshall, K. McCarthy, V. Sandt, K. Schwarte, J. Thonney, J. Waite, and E. Wishinski assisted in field measurements and experiments over the several years of observations Helpful comments on the manuscript were provided by $M$. Davis, J. Lin, R. N. Lipcius, and L. S. Marshall.

\section{LITERATURE CITED}

Abbott, R. T. (1974). American seashells, 2nd edn. Van Nostrand Reinhold, New York

Appeldoorn, R. S. (1988). Age determination, growth, mortality, and age of first reproduction in adult queen conch, Strombus gigas L., off Puerto Rico. Fish. Res. 6: 363-378

Appeldoorn, R. S., Dennis, G. D., Monterrosa-Lopez, O (1.987). Review of shared demersal resources of Puerto Rico and the lesser Antilles region. FAO Fish. Rep. 383, p. $36-106$

Berg, C. J. Jr, Olsen, D. A. (1989). Conservation and management of queen conch (Strombus gigas) fisheries in the Caribbean. In: Caddy, J. F. (ed.) Marine invertebrate fisheries: their assessment and management. Wiley, New York, p. 421-442

Bernstein, B. B, Williams, B. E., Mann, K. H. (1981). The role of behavioral responses to predators in modifying urchins' (Strongylocentrotus droebachiensis) destructive grazing and seasonal foraging patterns. Mar. Biol. 63: 39-49

Bertram, B. C. (1978). Living in groups: predators and prey In: Krebs, J. R., Davies, N. B. (eds.) Behavioural ecology: an evolutionary approach. Blackwell Scientific Publ., Oxford, p. 64-96

Brock, V. E., Riffenburgh, R. H. (1960). Fish schooling: a possible factor in reducing predation. J. Cons. int. Explor Mer 25: 307-317

Brownell, W. N. (1977). Reproduction, laboratory culture and growth of Strombus gigas, S. costatus, and S. pugilis in Los Roques, Venezuela. Bull. mar. Sci. 27: 668-680

Brownell, W. N., Stevely, J. M. (1981). The biology, fisheries, and management of the queen conch. Strombus gigas. Mar. Fish. Rev. 43: 1-12

Catterall, C. P., Poiner, I. R. (1983). Age- and sex-dependent patterns of aggregation in the tropical gastropod Strombus Iuhuanus. Mar. Biol. 77: 171-182

Crisp, D. L., Meadows, P. S. (1962). The chemical basis of gregariousness in cirripedes. Proc. R. Soc. Lond. B 156 : $500-520$

Davis, M., Hesse, C., Hodgkins, G. (1.987). Commercial hatchery produced queen conch, Strombus gigas, seed for research and grow-out market. Proc. Gulf Caribb. Fish. Inst. 38: 326-355

Dare, P. J. (1982). Notes on the swarming behavior and population density of Asterius rubens L. (Echinodermata: Asteroidea) feeding on the mussel, Mytilus edulis L. J Cons. int. Explor. Mer 38: 58-86 
Egan, B. D. (1985). Aspects of the reproductive biology of Strombus gigas. M.Sc. thesis, Univ. British Columbia, Vancouver

Elliot, J. M. (1979). Some methods for the statistical analysis of samples of benthic invertebrates. Freshwater Biol. Ass. Sci. Publ. No. 25

Fleeger, J. W., Palmer, M. A., Moser, E. B. (1990). On the scale of aggregation of meiobenthic copepods on a tidal mudflat. Mar. Ecol. 11: 227-237

Folt, C. L. (1987). An experimental analysis of costs and benefits of zooplankton aggregation. In: Kerfoot, W. C., Sih, S. (eds.) Predation: direct and indirect impacts on aquatic communities. Univ. Press New England, Hanover, p. $300-314$

Foster, W. A., Treherne, J. E. (1981). Evidence for the dilution effect in the selfish herd from fish predation on a marine insect. Nature 293:466-467

Hassell, M. P. (1978). The dynamics of arthropod predatorprey systems. Princeton Univ. Press, Princeton

Heip, C. (1975). On the significance of aggregation in some benthic marine invertebrates. In: Barnes, $H$. (ed.) Proc. 9th Eur. Mar. Biol. Symp. Aberdeen University Press, Aberdeen, p. 527-538

Herrnkind, W. F. (1985). Evolution and mechanisms of mass single-file migration in spiny lobster: synopsis. In: Rankin, M. A. (ed.) Migration: mechanisms and adaptive significance. Contr. mar. Sci. Univ. Texas (Suppl.) 27 197-211

Highsmith, R. C. (1982). Induced settlement and metamorphosis of sand dollar (Dendraster excentricus) larvae in predator-free sites: adult sand dollar beds. Ecology 63: $329-337$

Hoffman, D. L. (1989). Settlement and recruitment patterns of a pedunculate barnacle, Pollicipes polymerus Sowerby, off La Jolla, California. J. exp. mar. Biol. Ecol. 147. 83-98

Hurley, A. C. (1977). School structure of the squid Loligo opalescens. Fish. Bull. U.S. 76: 433-442

Kidd, N. A. C. (1982). Predator avoidance as a result of aggregation in the grey pine aphid, Schizolachnus pineti. J. Anim. Ecol. 51: 397-412

Knight-Jones, E. W. (1951). Gregariousness and some other aspects of settling behavior of Spirorbis. J. mar. biol. Ass. U.K. 30: 201-222

Lipcius, R. N., Stoner, A. W., Marshall, L. S. Jr, Bardales, A. T. (1991). Mass migration of juvenile queen conch (Strombus gigas) in the Bahamas. Proc. Gulf Caribb. Fish. Inst. 40; 299-302

Major, P. F. (1977). Predator-prey interactions in schooling fishes during periods of twilight: a study of the silverside Pranesus insularum in Hawaii. Fish. Bull. U.S. 75: 415-426

Marsden, J. R. (1991). Responses of planktonic larvae of the serpulid polychaete Spirobranchus polycerus var. augeneri to an alga, adult tubes and conspecific larvae. Mar. Ecol. Prog. Ser. 71: 245-251

Marshall, L. S. Jr (1992). Survival of queen conch, Strombus gigas, in natural seagrass habitats: impact of prey, predator and habitat features. Ph.D. dissertation, College of William and Mary, Williamsburg

Moulton, J. M. (1962). Intertidal clustering of an Australian gastropod. Biol. Bull. mar. biol. Lab., Woods Hole 123: $170-178$

O'Brien, D. P. (1989). Analysis of the internal arrangement of individuals within crustacean aggregations (Euphausiacea, Mysidacea). J. exp. mar. Biol. Ecol. 128: 1-30

Ormond, R. F. G., Campbell, A. C., Head, S. H., Moore, R. J., Rainbow, P. R., Saunders, A. P. (1973). Formation and breakdown of aggregations of the crown of thorns starfish, Acanthaster planci (L.). Nature 246: 167-168
Pawlik, J. R., Butman, C. A., Starczak, V R. (1991). Hydrodynamic facilitation of gregarious settlement of a reefbuilding tube worm. Science 251: 421-424

Pulliam, H. R., Caraco, T (1984). Living in groups: is there an optimal group size? In: Krebs, J. R., Davies, N. B. (eds.) Behavioural ecology: an evolutionary approach, 2nd edn. Sinauer Assoc., Sunderland, MA, p. 122-147

Randall, J. E. (1964). Contributions to the biology of the queen conch, Strombus gigas. Bull. mar. Sci. Gulf Caribb. 14: 246-295

Ray, M., Stoner, A. W. (1994). Experimental analysis of growth and survivorship in a marine gastropod aggregation: balancing growth with safety in numbers. Mar. Ecol. Prog. Ser. 105: 47-59

Robertson, R. (1961). The feeding of Strombus and related herbivorous marine gastropods. Not. Nat. Acad. Sci. Philadelphia 343: 1-9

Sandt, V. J., Stoner, A. W. (1993). Ontogenetic shift in habitat by early juvenile queen conch. Strombus gigas: patterns and potential mechanisms. Fish. Bull. U.S. 91: 516-525

Scheibling, R. E. (1980). Homing movements of Oreaster reticulatus (L.) (Echinodermata: Asteroidea) when experimentally translocated from a sand patch habitat. Mar. Behav. Physiol. 7: 225-232

Scheibling, R. E. (1985). Directional movement in a sea star (Oreaster reticulatus): adaptive significance and ecological consequences. In: Rankin, M. A. (ed.) Migration: mechanisms and adaptive significance. Contr. mar. Sci. Univ. Texas (suppl.) 27: 244-256

Scheibling, R. E., Hamm, J. (1991). Interactions between sea urchins (Strongylocentrotus droebachiensis) and their predators in field and laboratory experiments. Mar Biol. 110: 105-116

Skilleter, G. A. (1991). Distribution, abundance and size structure of cerithiid gastropods in sediments at One Tree Reef, southern Great Barrier Reef J. exp. mar. Biol. Ecol. 151: 185-207

Stoner, A. W. (1989a). Winter mass migration of juvenile queen conch Strombus gigas and their influence on the benthic enviroment. Mar. Ecol. Prog. Ser. 56: 99-104

Stoner, A. W. (1989b). Density-dependent growth and grazing effects of juvenile queen conch Strombus gigas L. in a tropical seagrass meadow. J. exp. Mar. Biol. Ecol. 130: 119-133

Stoner, A. W., Davis, M. (1994). Experimental outplanting of juvenile queen conch (Strombus gigas): comparison of wild and hatchery-reared stocks. Fish. Bull. U.S. 92: in press

Stoner, A. W., Hanisak, M. D., Smith, N. P., Armstrong, R. A. (1993). Large-scale distribution of queen conch nursery habitats: implications for stock enhancement. In: Appeldoorn, R. S., Rodriguez, B. (eds.) The biology, fisheries, mariculture and management of the queen conch. Fundación Cientifica Los Roques, Caracas

Stoner, A. W., Lipcius, R. N., Marshall, L. S. Jr, Bardales, A. T (1988). Synchronous emergence and mass migration in juvenile queen conch. Mar. Ecol. Prog. Ser. 49: 51-55

Stoner, A. W., Ray, M. (1993). Aggregation dynamics in juvenile queen conch (Strombus gigas): population structure, mortality, growth, and migration. Mar. Biol. 116: $571-582$

Stoner, A. W., Sandt, V J. (1991). Experimental analysis of habitat quality for juvenile queen conch in seagrass meadows. Fish. Bull. U.S. 89: 693-700

Stoner, A. W. Waite, J. M. (1990). Distribution and behavior of queen conch, Strombus gigas, relative to seagrass standing crop. Fish. Bull. U.S. 88: 573-585 
Stoner, A. W., Waite, J. M. (1991). Trophic biology of Strombus gigas in nursery habitats: diets and food sources in seagrass meadows. J. mollusc. Stud. 57: 451-460

Suer, A. L., Phillips, D. W. (1983). Rapid, gregarious settlement of the larvae of the marine echiuran Urechis caupo Fisher and MacGinitie 1928. J. exp. mar. Biol. Ecol 67: 243-259

Tegner, M. J., Levin, L. A. (1983). Spiny lobsters and sea urchins: analysis of a predator-prey interaction. $\mathrm{J}$. exp

This article was submitted to the editor mar. Biol. Ecol. 73: 125-150

Turchin, P. (1989). Population consequences of aggregative movement. J. Anim. Ecol. 58: 75-100

Vadas, R. L., Elner, R. W., Garwood, P. E., Babb, I. G. (1986). Experimental evaluation of aggregation behavior in the sea urchin Strongylocentrotus droebachiensis: a reinterpretation. Mar. Biol. 90: 433-448

Wilson, E. O. (1975). Sociobiology: the new synthesis. Harvard Univ. Press, Cambridge, MA

Manuscript first received: September 13, 1993

Revised version accepted: December 10,1993 